УДК 351:316.4:616-084

DOI: https://doi.org/10.26642/jen-2020-4(94)-117-122

О.І. Білик, к.е.н., доц.

Національний університет «Львівська політехніка»

\title{
Вплив пандемії на зміну системи управління соціальними ризиками
}

Раптове виникнення пандемії COVID-19 трансформувало соиіальне середовище у всьому світі, щуо вплинуло на зміну траєкторії соціальних ризиків. Спалах COVID-19 у грудні 2019 року поставив людство в надзвичайний стан. Швидке поширення вірусу становить подвійний ризик: пандемія ставить суспільство в особливо ризиковану політичну, економічну та соціальну ситуацію. 3 іншого боку, співіснування людей в суспільстві стає ризиком для здоров'я певних сочіальних груп та суб'єктів, щуо, у свою чергу, є початком для далекосяжних політичних, економічних та сочіальних ризиків. Різкі обмеження, введені державами в контексті соціального дистанціювання (враховуючи блокування) для стримування пандемії, були чітко помітні для суспільства. У деяких випадках вони викликали радикальні потрясіння у повсякденному житті кожного. На даний момент поки неможливо передбачити, в який період $i$ в якому порядку втручання в економічне та сочіальне життя будуть повністю закінчені. Саме це спричиняє виникнення нових соціальних ризиків. Інші соціальні наслідки пандемії, такі як втрата робочих місиь у особливо постраждалих галузях, матимуть, швидие за все, довгостроковий ефект у майбутньому. Стаття побудована на основі емпіричних досліджень розкрито виникнення нових соціальних ризиків і зміни стратегії управління ними. Також важливим $\epsilon$ і дослідження різностороннього впливу пандемії на суспільство та навколишнє середовище в цілому. В статті доведено, щзо зовнішні потрясіння чи кризи можуть бути пусковими механізмами або каталізаторами сочіально бажаних перетворень, які також відомі як «стрибок уперед». Прочедури, які створила криза, слугують для того, щуоб шукати підходи до неминучої терміновоі сочіально-екологічної трансформації суспільства. Оскільки ия трансформація має створити стійкі та справедливі у всьому світі способи життя й економіки, тому в статті порушується питання про те, щзо важливо для забезпечення зміни в системі управління соціальними ризиками з метою забезпечення сочіальної безпеки країни в цілому.

Ключові слова: сочіальні ризики; пандемія; COVID-19; управління соціальними ризиками; соичіальна дистаниія; соичіальна ізоляція.

Актуальність теми. Пандемія COVID-19 є не лише серйозною загрозою для суспільства з точки зору громадського здоров'я, але також має суттєві наслідки для інших нагальних соціальних питань, таких як економічна і соціальна безпека, демократія та гендерна рівність. За короткий час пандемія спричинила жорстоку світову кризу безробіття. Це непропорційно вплинуло на становище расових, етнічних та релігійних меншин, призвело до актів міжгрупової ворожості та погіршило становище жінок. Хоча пандемія могла тимчасово зменшити вплив людської діяльності на клімат, тиск на перезапуск економіки, ймовірно, негативно вплине на норми, введені в боротьбу зі зміною клімату. Отже, очевидно, що пандемія - це не просто проблема охорони здоров'я, і вона матиме важливі наслідки для багатьох інших соціальних проблем. Тому питання про те, як вплине пандемія COVID-19, є важливим і вимагає ретельного вивчення.

Аналіз останніх досліджень. Серед основних науковців, які присвятили свої доробки вивченню феномена соціального ризику, слід вирізнити таких вітчизняних та іноземних дослідників, як У.Бек [1], В. Вітлінський [2], А.Вілдавскі [3], Е.Гіденс [4], О.Грішнова [5], К.Дейк [3], М.Дуглас [6], В.Зубков [7], С.Корецька [8] Е.Лібанова [9], Н.Луман [10]. Сучасні проблеми впливу пандемії на трансформації соціальної системи розкрили у своїх працях Л.Черенько [11], О.Новікова [12], О.Панькова [13].

Мета статті - висвітлити на основі емпіричного дослідження вплив пандемії на зміну системи управління соціальними ризиками.

Викладення основного матеріалу. Пандемія, спричинена коронавірусом, є динамічною подією, яка визначається багатьма факторами, особливо поведінкою людини (наприклад, гігієнічною поведінкою та соціальними контактами), і тому дуже мінлива. Сучасна ситуація продемонструвала, наскільки важко обмежити системні ризики, які спричиняють пандемії в епоху стрімких глобальних потоків людей, товарів та інформації. 3 одного боку, патогени швидко поширюються по всьому світі 3 ефективними міжнародними пасажирськими перевезеннями. По-друге, наслідки пандемії не обмежуються системою охорони здоров'я. Пандемія зачіпає всі життєво важливі системи нашого суспільства - від продовольчого забезпечення, економічної та фінансової системи, системи освіти до культурного та соціального життя. I не лише в деяких кризових районах, а й у всьому світі.

(C) О.І. Білик, 2020 
Впродовж пандемії уряди приймають диференційовані рішення щодо зміни системи управління соціальними ризиками. Кожна із прийнятих стратегій має далекосяжні наслідки, повний обсяг яких стане очевидним лише 3 часом. Вплив на економіку вже величезний. Світові уряди розпочали масштабні заходи допомоги для стабілізації економіки та фінансових ринків. Але, як зазначалося, ці заходи призводять до виникнення та посилення наслідків соціальної ізоляції, що спонукає до відновлення суспільного життя 3 метою пом'якшення негативних наслідків для економіки. Ризики невжиття будь-яких або неадекватних контрзаходів для захисту населення мають бути зважені з ризиками, які становлять втручання у всі сектори суспільства: енергетика, інфраструктура, харчування, транспорт тощо.

Важливим є окреслення в умовах пандемії поняття «соціальної справедливості», адже пандемії інфекційних хвороб, як COVID-19, не нівелюють зобов'язання щодо соціальної справедливості. Таким чином, соціальне дистанціювання має дотримуватися принципів та цінностей соціальної справедливості. Застосування заходів соціального дистанціювання виявилося важливим для стримування поширення пандемії COVID-19 і буде продовжувати залишатися важливим заходом у найближчі місяці. Проте введення цих заходів справедливе і вимагає надання соціальної підтримки особам, які є соціально та політично маргіналізованими або знедоленими, наприклад, особам, які не мають житла або проживають у громаді, працівникам-мігрантам, ув'язненим та особам із нижчим соціальним статусом.

Отже, пандемія як соціальний ризик має системний характер, який впливає на всі сфери суспільного життя. Як вже зазначалося, найбільше пандемія впливає на вразливі верстви населення. Так, за даними Світового банку, COVID-19 призвів до збільшення кількості людей, які потрапили в крайню бідність у 2020 році, до 100 мільйонів (виміряно за міжнародною межею бідності, що становить 1,90 долара на день) проти 71 мільйона на початок періоду [14]. В Україні рівень бідності зросте з 27 до 44 \% [15]. Окрім зменшення доходів та зростання безробіття, виникає ще один такий вид ризику, як соціальна ізоляція, яка $€$ різною для різних верств населення. наслідками соціальної ізоляції може стати низка захворювань, спричинених психічними розладами. Сьогодні вже науковці прогнозують, що пандемія коронавірусу призведе до іншої пандемії: у світі може спостерігатися значне збільшення захворюваності на психічні розлади, і одним із факторів, що відповідають за це, буде соціальна ізоляція, вимушена зовнішніми факторами, і хронічний стрес, пов'язаний з нею. Також пандемія викликала необхідність переведення частини працівників на дистанційну роботу, серед недоліків якої є:

- відсутність чіткого планування робочого часу;

- відсутність комунікацій, що призводить до сповільнення виконання деяких обов'язків (більше часу необхідно для того, щоб зв'язатися з іншим працівником, технічні причини тощо);

- недостатня кваліфікація для виконання деяких видів роботи дистанційно;

- додаткові витрати для обладнання дистанційного місця праці (необхідність закупівлі додаткового обладнання, витрати на електроенергію тощо);

- зниження комфорту проживання або відсутність умов для дистанційної роботи;

- важкий психологічний стан через неможливість диференціації роботи із хатніми обов'язками.

На рисунку 1 продемонстровано структуру недоліків під час дистанційної роботи. Слід підкреслити, що в діловій практиці існує думка, що люди, які працюють віддалено, не виконують свою роботу так само добре, як коли вони фізично присутні в офісі. Багато роботодавців має обмежену довіру до своїх працівників і внутрішню впевненість, що прямий контроль $\epsilon$ найвищою формою довіри. Як видно 3 рисунка 1, фактично 45 \% опитаних роботодавців, які здійснюють організацію праці дистанційно, занепокоєні відсутністю візуального контролю за працівниками.

Серед працівників найбільше занепокоєння викликає зміна формату організації роботи (60 \%).

Отже, соціальна ізоляція та збідніння населення підпорядковує багатьох громадян трьом формам ризику:

1) біологічні ризики, пов'язані з вірусом COVID-19 (SARS-CoV-2);

2) ризики, пов'язані з соціальним дистанціюванням;

3) ризики, що супроводжують часто некритичну залежність від прийняття рішень щодо охорони здоров'я під час пандемій на принципі, який змушує нас виробляти найбільше благо для найбільшої кількості людей (тобто принцип корисності).

Заходи соціального дистанціювання, що застосовуються у всьому світі, мають негайно намагатися мінімізувати ці ризики, щоб найбільші наслідки цієї кризи не зачепили найуразливіші верстви населення.

Саме соціальна ізоляція як працюючого, так і непрацюючого населення може стати одним із каналів впровадження гібридної інформаційної війни. Сьогодні переважною стратегією державних та недержавних суб'єктів є використання дезінформації або кібератак для знищення довіри до влади та активізації соціальних та/або політичних заворушень, наприклад, підриваючи функціонування служб та інфраструктури, сприяючи екстремізму чи насильству та використовуючи існуючі політизовані проблеми, починаючи з виборів до міграцій та пандемій. Такі дії дестабілізації часто дешевші за збройні атаки - вони створюють невидимі загрози, які часто важко виявити та відстежити. Слід зауважити, що в умовах соціальної ізоляцій вплив таких заходів є набагато сильнішим, адже за умови зменшення можливостей 
комунікувати і дискутувати суспільство отримує інформацію з різних інтернет-джерел та ЗМІ. Сучасні загрози суспільству дедалі частіше породжуються невійськовими засобами та без застосування сили.

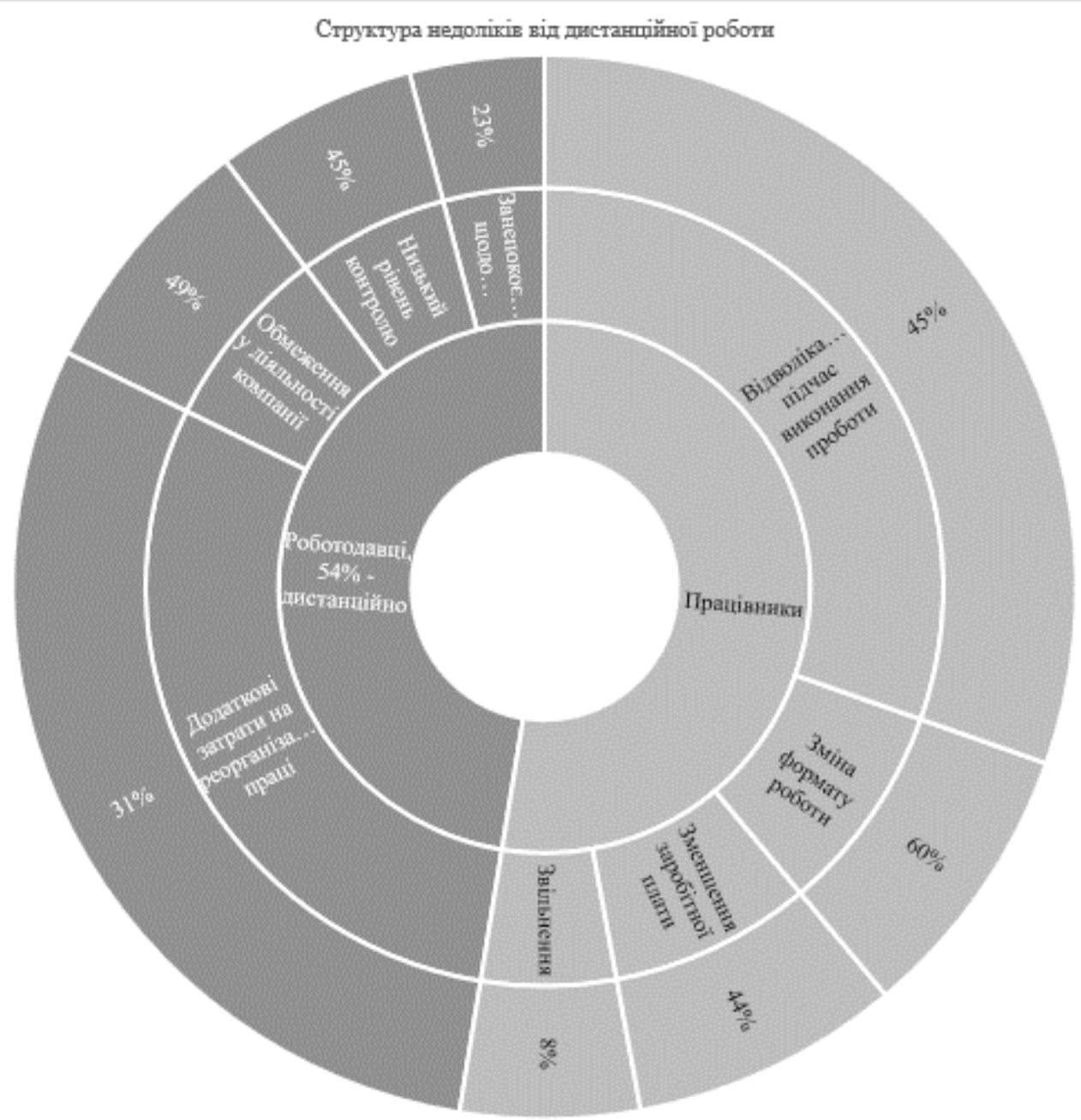

Рис. 1. Структура недоліків дистанційної роботи (складено автором на основі [16])

Аналізуючи перелічені вище соціальні наслідки пандемії, слід зазначити, що в цих умовах необхідно формувати стійкість суспільства через інформаційні канали. Стійкість $є$ важливою складовою комплексного підходу, а цивільна стійкість (як інституційна, так і всередині самого суспільства) має вирішальне значення. Сюди належить покращення ситуативної обізнаності та чіткого розуміння змін відносин між цивільною та військовою зонами, але надаються пріоритети цивільному керівництву, заснованому на довірі між цивільними та владою співпрацювати та підтримувати одне одного в кризовій ситуації. Підтримка добре освіченого та обізнаного суспільства має важливе значення для успішного впровадження комплексного підходу. Незалежна та прозора інформація / засоби масової інформації, разом із освітніми програмами, які мають бути суворими, науково обізнаними та соціально відповідальними, $\epsilon$ надзвичайно важливими у кризові періоди.

Тому потрібно переробити комплексний підхід, враховуючи поточний контекст, вивчаючи дані про коронавірус у реальному часі та будуючи інформаційні потоки знизу вгору на рівні громади. Слід скласти карту ресурсів та активів, які вже існують у громаді, таких як: розробка освітніх програм, роль місцевих організацій громадянського суспільства та можливість швидкого набору добровольців; наявність та надійність місцевих ресурсів (транспорту, енергетики, зв'язку, харчування та води); статус муніципальних центрів зв'язку та підрозділів готовності, а також те, як працює довіра громадськості на місцевому, регіональному та національному рівнях.

Тому під час формування суспільної стійкості необхідно враховувати всі можливості від інформатизації суспільства, зокрема і через посилення цифрової обізнаності.

У таблиці 2 сформовано основні зміни у системі управління соціальними ризиками в період пандемії. 
Таблиия 1

Напрями зміни системи управління сочіальними ризиками під час пандемії (сформовано автором)

\begin{tabular}{|c|c|c|c|c|c|c|c|c|c|}
\hline $\begin{array}{c}\text { При- } \\
\text { чина } \\
\text { виник- } \\
\text { нення } \\
\text { ризику }\end{array}$ & $\begin{array}{c}\text { Вид } \\
\text { ризи- } \\
\text { ку }\end{array}$ & $\begin{array}{l}\text { Харак- } \\
\text { тер } \\
\text { ризику }\end{array}$ & $\begin{array}{c}\text { Категорія } \\
\text { первинних } \\
\text { наслідків } \\
\text { ризику }\end{array}$ & Дії & $\begin{array}{c}\text { Категорія } \\
\text { вторинних } \\
\text { наслідків } \\
\text { ризику }\end{array}$ & $\begin{array}{l}\text { Категорія } \\
\text { третинних } \\
\text { наслідків }\end{array}$ & $\begin{array}{c}\text { Учасники } \\
\text { системи } \\
\text { управління } \\
\text { соціальними } \\
\text { ризиками }\end{array}$ & $\begin{array}{c}\text { Мета } \\
\text { заходів }\end{array}$ & $\begin{array}{c}\text { Заходи в системі } \\
\text { управління } \\
\text { соціальними } \\
\text { ризиками }\end{array}$ \\
\hline \multirow{7}{*}{ 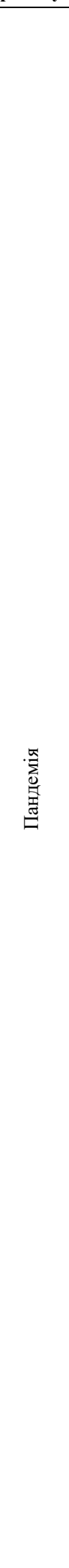 } & \multirow{7}{*}{ 罚 } & \multirow{7}{*}{ है } & 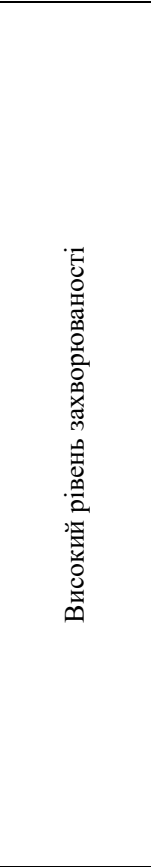 & \multirow{7}{*}{ 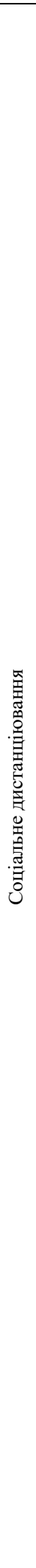 } & 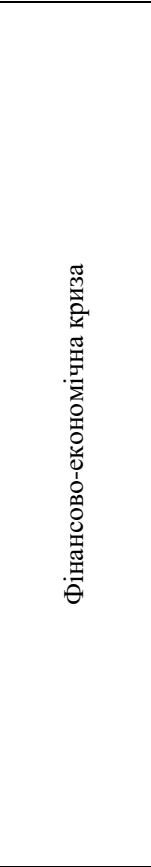 & \multirow[t]{2}{*}{ 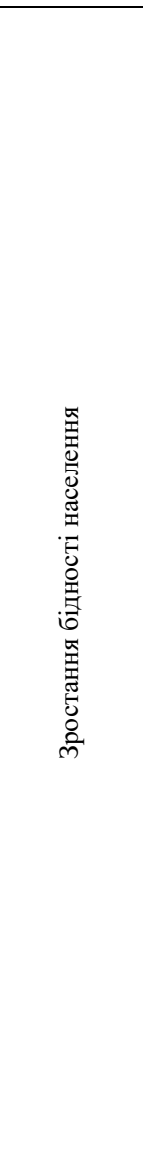 } & 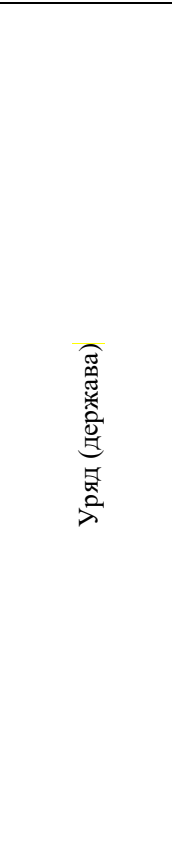 & \multirow{7}{*}{ 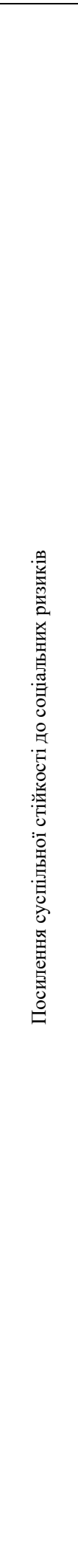 } & $\begin{array}{l}\text { Перерозподіл } \\
\text { державних коштів у } \\
\text { кризові «зони». } \\
\text { Створення умов для } \\
\text { інформатизації і } \\
\text { забезпечення цифрової } \\
\text { грамотності населення. } \\
\text { Створення умов для } \\
\text { підтримки бізнесу } \\
\text { шляхом запровадження } \\
\text { програм податкових } \\
\text { преференцій під час } \\
\text { карантинних обмежень. } \\
\text { Створення умов для } \\
\text { розвитку } \\
\text { інфраструктури. } \\
\text { Сприяння інноваційному } \\
\text { розвитку у сфері } \\
\text { цифровізації, освіти, } \\
\text { науки і медицини. } \\
\text { Розроблення програм } \\
\text { підтримки малого } \\
\text { бізнесу. Міжнародна } \\
\text { співпраця з метою } \\
\text { мінімізації пандемії } \\
\text { Посилення роботи } \\
\text { соціальних служб }\end{array}$ \\
\hline & & & 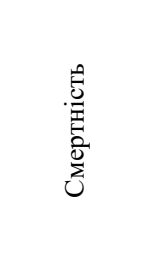 & & 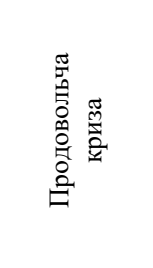 & & 预 & & $\begin{array}{l}\text { Підтримання } \\
\text { профілактичних } \\
\text { заходів, які сприяють } \\
\text { зменшенню поширення } \\
\text { коронавірусу. } \\
\text { Підтримка вразливих } \\
\text { верств населення. } \\
\text { Навчання }\end{array}$ \\
\hline & & & \multirow{5}{*}{ 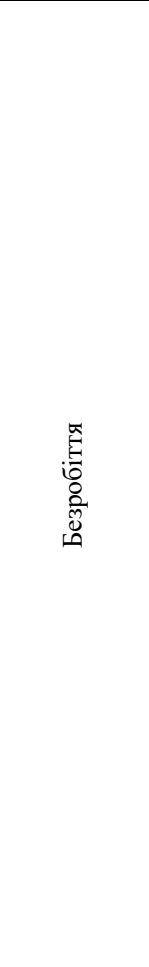 } & & 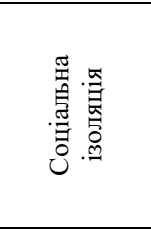 & 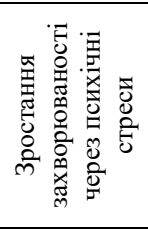 & 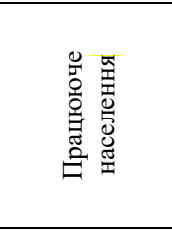 & & $\begin{array}{l}\text { Розроблення чіткого } \\
\text { робочого графіка. } \\
\text { Комунікація за } \\
\text { допомогою новітніх } \\
\text { технологій. } \\
\text { Пошук можливостей } \\
\text { професійного розвитку }\end{array}$ \\
\hline & & & & & \multirow{4}{*}{ 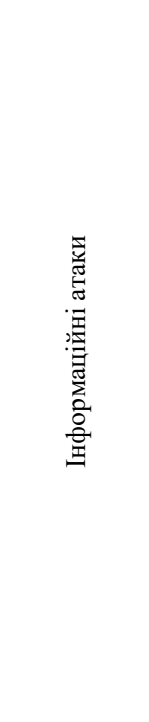 } & \multirow{4}{*}{ 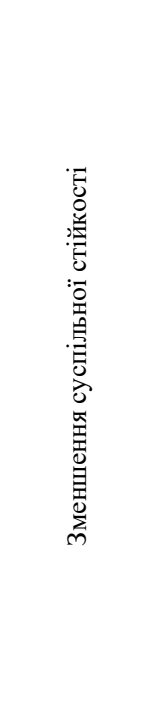 } & 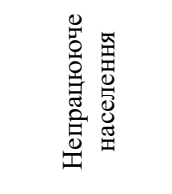 & & $\begin{array}{l}\text { Перекваліфікація } \\
\text { та навчання }\end{array}$ \\
\hline & & & & & & & 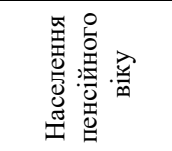 & & $\begin{array}{l}\text { Дотримання } \\
\text { рекомендацій щодо } \\
\text { непоширення пандемії }\end{array}$ \\
\hline & & & & & & & 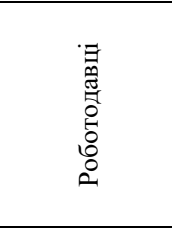 & & $\begin{array}{l}\text { Створення належних } \\
\text { умов організації праці. } \\
\text { Комунікативні заходи, } \\
\text { які включають } \\
\text { щотижневі онлайн- } \\
\text { зустрічі (формальні і } \\
\text { ненормальні) }\end{array}$ \\
\hline & & & & & & & 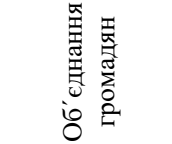 & & $\begin{array}{l}\text { Допомога особам в } \\
\text { зоні ризику, } \\
\text { інформаційна допомога }\end{array}$ \\
\hline
\end{tabular}


Слід зауважити, що пандемія COVID-19, попри очевидні негативні наслідки, виконує і низку позитивних функцій, зокрема: підсилення контролю (за охороною здоров'я, фінансами, соціальними ризиками), інноваційну функцію (активізація наукового потенціалу як у сфері пошуку шляхів боротьби 3 пандемією, так і в інших галузях - освітній, розвитку цифровізації ), підвищення культури особистої гігієни, покращення інформаційної функції, підвищення рівня цифрової культури населення.

Висновки та перспективи подальших досліджень. Інноваційні підходи до створення потенціалу для боротьби з соціальними ризиками під час COVID-19 є невід'ємною частиною стратегій багатьох країн. Підхід «знизу вгору» при розробленні заходів у системі управління ризиками під час пандемії забезпечить основу для визначення подальших ініціатив або виявлення недоліків, які необхідно усунути, враховуючи національні ініціативи з готовності до надзвичайних ситуацій, що підтримують цивільне населення, оцінку та профілактичне покращення ключових державних послуг (охорона здоров'я, транспорт, інфраструктура) та інтенсивні навчання із залученням численних цивільних центрів. Тому формування заходів розвитку цих напрямів в умовах пандемії вимагають подальшого грунтовного наукового дослідження.

\section{Список використаної літератури:}

1. Бек У. Общество риска на пути к другому модерну / У.Бек. - М. : Прогресс-Традиция, 2000. - 267 с.

2. Вітлінський В.В. Ризикологія в економіці та підприємництві : монографія / В.В. Вітлінський, Г.І. Великоіваненко. - К. : КНЕУ, 2004. - 480 с.

3. Вилдавски A. Теории восприятия риска: кто боится, чего и почему? / А.Вилдавски, К.Дейк // THESIS: теория и история экономических и социальных институтов и систем. - 1994. - № 5. - С. 135-160.

4. Гіденс E. Нестримний світ: як глобалізація перетворює наше життя : монографія / E.Гіденс. - К. : Альтерпрес, 2004. $-100 \mathrm{c}$.

5. Грішнова О.А. Соціальна відповідальність у трудових відносинах: теорія, практика, регулювання ризиків : монографія / О.А. Грішнова, Г.Ю. Мішук, О.О. Олійник. - Рівне : НУВГП, 2014. - 216 с.

6. Дуглас М. Риск как судебный механизм / М.Дуглас // THESIS: теория и история экономических и социальных институтов и систем. - 1994. - № 5. - С. 125-135.

7. Зубков В.И. Социологическая теория риска : монография / В.И. Зубков. - М. : Изд-во РУДН, 2013. -310 с.

8. Корецька С.О. Соціальна політика України: теорія, методологія, механізми реалізації : монографія / С.О. Корецька. - Донецьк : Юго-Восток, 2010. - 445 с.

9. Людський розвиток в Україні: мінімізація соціальних ризиків (колективна науково-аналітична монографія)/ За ред. Е.M. Лібанової. - К. : Ін-т демографії та соціальних досліджень ім. М.В. Птухи НАН України ; Держкомстат України, 2010. - 496 с.

10. Луман Н. Понятие риска / Н.Луман // THESIS: теория и история экономических и социальных институтов и систем. - 1994. - № 5. - С. 135-160.

11. Вплив коронавірусної кризи на бідність: перші наслідки для України / Л.М. Черенько, С.В. Полякова, B.C. Шиикін та ін. ; Нац. акад. наук. Укр., Ін-т демогр. та соц. дослідж. ім. М.В. Птухи. - Київ, 2020 [Електронний ресурс]. - Режим доступу: https://idss.org.ua/arhiv/poverty_forecast.pdf.

12. Новікова О.Ф. Цифровий розвиток у процесах подолання ризиків та небезпек в умовах пандемії COVID-19/ О.Ф. Новікова, О.В. Панькова, А.Д. Шастун // Бізнес-навігатор. - 2020. - Вип. 4(60).

13. Панькова O.B. Інформаційно-комунікативне забезпечення в процесах протидії ризикам та загрозам пандемії COVID-19 у трудовій сфері України / О.В. Панькова, А.Д. Шастун., Д.В. Паньков // Матеріали IX Міжнародної науково-практичної конференції «Science and practice of today», Анкара, Туреччина (1619 листопада 2020 р.) [Електронний ресурс]. - Режим доступу : https://isg-konf.com/uk/science-and-practice-oftoday-ua/?utm_source=eSputnikpromo\&utm_medium=email\&utm_campaign=Zb\%D1\%96rnik_mater\%D1\%96al\%D1\%96v_konferenc\%D1\%96\% D1\%97_\%D1\%94_dostupnim.\&utm_content=970129055\&etm_term=aWlkPTVkZmE5MTViLWExZmUtNGI5Z

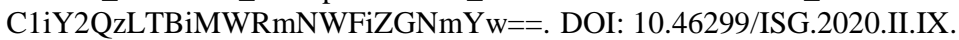

14. Updated estimates of the impact of COVID-19 on global poverty: The effect of new data / Christoph Lakner, Nishant Yonzan, Daniel Gerszon Mahler et al. // Світовий банк. - 2020 [Електронний ресурс]. - Режим доступу : https://blogs.worldbank.org/opendata/updated-estimates-impact-covid-19-global-poverty-effect-new-data.

15. Сарахман Е. Кількість бідних в Україні різко збільшиться - ЮНІСЕФ / Е.Сарахман // Українська правда. 2020 [Електронний ресурс]. - Режим доступу : https://www.epravda.com.ua/news/2020/05/18/660598/.

16. 58 \% працівників не проти продовжувати роботу віддалено - опитування // Профспілка працівників освіти та науки України. - 2020 [Електронний ресурс]. - Режим доступу : https://pon.org.ua/novyny/8155-58-pracvnikvne-proti-prodovzhuvati-robotu-vddaleno-opituvannya.html.

\section{References:}

1. Bek, U. (2000), The risk society on the way to another modernity, Progress-Tradicija, Moscow.

2. Vitlinskij, V.V. (2004), The risks in the economy and entrepreneurship, KNEU, Kiev.

3. Vildavskij, A. and Deyke, K. (1994), «Theories of risk's perception: who is afraid and why?», THESIS: teoriya $i$ istoriya ekonomicheskikh i sotsial'nykh institutov i sistem, No. 5, pp. 135-160.

4. Gidens, E. (2004), Expendables world: as globalization transforms our lives, Alterpres, Kiev, 100 p.

5. Grischnova, O.A., Mishhuk, G.Ju. and Olijnyk, O.O. (2014), Social responsibility in labor relations: theory, practice, risk's management, NUVGP, Rivne, 2016 p. 
6. Duglas, M. (1994), «Risk kak sudebnyi mekhanizm», THESIS: teoriya i istoriya ekonomicheskikh i sotsial'nykh institutov i sistem, No. 5, pp. 125-135.

7. Zubkov, V.I. (2013), Sotsiologicheskaya teoriya riska, monografiya, Izd-vo RUDN, M., 310 p.

8. Korec'ka, S.O. (2010), Social policy of Ukraine: theory, methodology, mechanisms of implementation, Jugo-Vostok, Donec'k, $445 \mathrm{p}$.

9. Libanova, E.M. (ed.) (2010), Ljuds'kyj rozvytok v Ukrai'ni: minimizacija social'nyh ryzykiv (kolektyvna naukovoanalitychna monografija), In-t demografii' ta social'nyh doslidzhen' im. M.V. Ptuhy NAN Ukrai'ny, Derzhkomstat Ukrai'ny, K., 496 p.

10. Luman, N. (1994), «The Concept of the risk», THESIS: teoriya i istoriya ekonomicheskikh $i$ sotsial'nykh institutov $i$ sistem, No. 5, pp. 135-160.

11. Cheren'ko, L.M., Poljakova, S.V. and Shyshkin,V.S. et al. (2020), Vplyv koronavirusnoi' kryzy na bidnist': pershi naslidky dlja Ukrai'ny, Nac. akad. nauk. Ukr., In-t demogr. ta soc. doslidzh. im. M.V. Ptuhy, Kyi'v, [Online], available at: https://idss.org.ua/arhiv/poverty_forecast.pdf

12. Novikova, O.F., Pan'kova, O.V. and Shastun, A.D. (2020), «Cyfrovyj rozvytok u procesah podolannja ryzykiv ta nebezpek v umovah pandemii' COVID-19», Biznes-navigator, Issue 4 (60).

13. Pan'kova, O.V., Shastun, A.D. and Pan'kov, D.V. (2020), «Informacijno-komunikatyvne zabezpechennja v procesah protydii' ryzykam ta zagrozam pandemii' COVID-19 u trudovij sferi Ukrai'ny», Materialy IX Mizhnarodnoi' naukovopraktychnoi' konferencii' «Science and practice of today», Ankara, Turechchyna (16-19 lystopada 2020 r.), [Online], available at: https://isg-konf.com/uk/science-and-practice-of-today-ua/?utm_source=eSputnikpromo\&utm_medium=email\&utm_campaign $=$ Zb $\%$ D1\%96rnik_mater\%D1\%96al\%D1\%96v_konferenc\%D1\%96\% D1\%97_\%D1\%94_dostupnim.\&utm_content=970129055\&etm_term=aWlkPTVkZmE5MTViLWExZmUtNGI5ZC 1iY2QzLTBiMWRmNWFiZGNmYw==, doi: 10.46299/ISG.2020.II.IX.

14. Lakner, Christoph, Yonzan, Nishant and Mahler et al. (2020), «Updated estimates of the impact of COVID-19 on global poverty: The effect of new data», The World Bank, [Online], available at: https://blogs.worldbank.org/opendata/updated-estimates-impact-covid-19-global-poverty-effect-new-data

15. Sarahman, E. (2020), «Kil'kist' bidnyh v Ukrai'ni rizko zbil'shyt'sja - JuNISEF», Ukrai'ns'ka pravda, [Online], available at: https://www.epravda.com.ua/news/2020/05/18/660598/

16. $58 \%$ pracivnykiv ne proty prodovzhuvaty robotu viddaleno - opytuvannja (2020), Profspilka pracivnykiv osvity ta nauky Ukrai'ny, [Online], available at: https://pon.org.ua/novyny/8155-58-pracvnikv-ne-proti-prodovzhuvatirobotu-vddaleno-opituvannya.html

Білик О.І. - кандидат економічних наук, доцент Національного університету «Львівська політехніка».

Стаття надійшла до редакції 29.09.2020. 